\title{
ЗАСТУПЉЕНОСТ И РЕЦЕПЦИЈА ЗАХАРИЈЕ ОРФЕЛИНА У ИСТРАЖИВАЮИМА СРПСКЕ ЛИНГВИСТИКЕ НОВИЈЕГ ДОБА
}

\begin{abstract}
Језички период који претходи стандардизацији српског књижевног језика на народној основи од стране Вука Стефановића Караџића, познатији под називом славеносрпски период, иако од значаја за српску историјску лингвистику, био је након језичке реформе великим делом запостављен. Заједно са њиме су такође готово у заборав пале и многе значајне личности којима су српска наука и култура остале умногоме дужне. Међу њима се, према мишљењу аутора, може наћи и Захарија Орфелин - због чега је као тема дефинисано испитивање рецепције његовог лика и дела у контексту српске модерне лингвистике. У раду ће, сходно томе, бити дат један својеврсни библиографски преглед изабране доступне литературе о Захарији Орфелину, у чему ће се огледати његова корисност за науку и даља научна истраживања.
\end{abstract}

Кључне речи: Захарија Орфелин, просветитељство, историјска србистика, библиографски преглед.

1. Као тема овог рада дефинише се Захарија Орфелин (1726-1785) и рецепција његове личности и стваралаштва у модерној српској науци, а пре свега у србистици (дакле, са фокусом на филолошким аспектима Орфелиновог рада). С друге стране, у раду ће бити речи и о његовом конкретном стваралачком корпусу - где ће бити приказано у којој мери и на који начин су његова дела до сада анализирана и у каквим контекстима је та анализа вршена.

Од значаја је скренути пажњу и на начин обрађивања тематске грађе који ће у наставку бити заступљен. Теми ће овог пута бити приступљено хронолошки, па ће тако најзначајнији истраживачки радови о Захарији Орфелину бити приказани ради веће прегледности највећим делом према редоследу свог настајања. Наведени критеријум поделе биће заступљен претежно због

\footnotetext{
“aleksandragagic6@gmail.com
} 
тога што великим делом одражава и такозване „фазе” у истраживањима о Орфелину.

2. Први период истраживања карактеришу непотпуне и тешко доступне информације о Орфелиновом стваралаштву, као и многе несигурности у погледу ауторства неких од његових данас најпознатијих дела. На многим својим делима, Орфелин се није потписао, што онима који би се подухватили исцрпније обраде те грађе свакако није олакшавало посао. ${ }^{1}$

Као централно дело у овом периоду намеће се студија Тихомира Остојића Захарија Орфелин, живот и рад му из 1923. године - која, што ће се у продужетку рада видети, и до данашњег дана остаје најисцрпнија студија на тему. Нажалост Остојић своју студију није успео да приведе крају, али она ипак представља извор највеће количине информација којима се у истраживањима о Орфелину и данас користимо.

Пре свега, Остојић обрађује комплетну дотадашњу литературу о Захарији Орфелину и његовом раду. Он креће од самих почетака, односно од прве књиге у којој се појављују било какви подаци о Орфелину. Према његовим наводима, то је лексикон Елека Хорањија под називом „Memoria Hungarorum et Provincialium scriptis editis notorum" (1776). Ово дело је, према Остојићу, веома значајно превасходно због тога што, упркос ретким грешкама, представља извор информација датих од стране Орфелина лично (Остојић 1923: 11-12). Након неколико наредних извора у којима се Орфелин спомиње, али само у до тада већ познатим оквирима, наведени су и ситнији прикази аутора са нешто нових информација и идеја - на пример, Франца Карла Алтера у „Allgemeiner litterarischer Anzeiger”, који износи своје тумачење презимена „Орфелин”, ${ }^{2}$ прилог у „Магазину за художество, књижество и моду”, у коме се први пут након Хорањија допуњава до тада позната библиографија, као и Ивана Кукуљевића Сакцинског, који је, према Остојићевом мишљењу, први обратио пажњу на Орфелина „као резача и цртача” и још других (Остојић

\footnotetext{
${ }^{1}$ Узроци овој појави били су различити - неки истраживачи спекулисали су о његовој повученој природи лишеној егзибиционистичких побуда, неки су у томе видели одраз тежњи ка мистериозности једног уметника, док су трећи разлоге за тражење анонимности приписивали повремено контроверзним делима Орфелиновим, некада упереним и против највиших црквених великодостојника. Из перспективе присталица идеје о Православној Славији као широј историјској и културној парадигми (в. Кречмер 2000: 543 или Толстој 2007: 148), могуће је принети још једну могућност тумачења овог питања. Како је ову парадигму карактерисало одсуство индивидуалног стваралаштва, ,jер се свако стваралаштво у православној култури схватало као служење Богу" (Кречмер 1996: 33), могуће је у њеним оквирима приписати ову врсту намере Захарији Орфелину као ствараоцу дела, чија су схватања формирана унутар наведене парадигме.

${ }^{2} \mathrm{O}$ овом веома интересантном питању ни до данашњег дана у науци не постоји консензус. Ф. К. Алтер се први запитао о значењу Орфелиновог необичног презимена, тврдећи да је оно настало као комбинација имена Orpheus и Linus, па према томе као израз његове песничке склоности. Томе се успротивио Т. Остојић, повезујући га на почетку са француском речју „orphelin” у значењу „сироче”, да би касније добио нову идеју о томе како је ово презиме заправо Орфелин сам себи наденуо по узору на француског истоименог гравера (Остојић, 1923: 34). Занимљиву идеју даје и Никола Радојчић у свом раду који ће даље бити споменут, а то је да „орфелин” може представљати и „камен на врху царске круне” (Радојчић 1933: 254). Овог питања се неколико деценија касније дотакао и Динко Давидов, наводећи Алтерово мишљење као „прихватљивије” од Остојићевог, а Радојчића и не спомиње (Давидов 1978: 160). У вези са конкретном подтемом могуће је консултовати и један савремени рад аутора Владимира Симића (2016).
} 
1923: 12-14). Остојићев савременик, Димитрије Руварац, такође је заступљен у студији, и то са неколико наведених чланака. Руварчев натпросечно велики допринос биће обрађен одвојено мало даље у раду.

Што се тиче садржајног дела студије Тихомира Остојића - аутор је покрио готово сва питања која су у време њеног писања била у оптицају. ${ }^{3}$ Највише празнина се појављује у биографском делу, где он признаје да о појединим годинама његовог живота нема никаквих информација (в. Остојић 1923: 28). Поред неколико темељних поглавља о конкретним Орфелиновим делима, до данас недопуњену и можда најбоље обрађену област ове студије представљају извори из његове личне библиотеке, према Остојићевим наводима - тада највеће приватне библиотеке у Срба (Остојић 1923: 39). Важно је навести и да је он у Орфелину препознао зачетке просветитељских идеја, чиме је додатно нагласио још један аспект са кога је Орфелина као ствараоца битно посматрати и изучавати.

Остојић је аутор још неколико краћих радова који се баве Орфелином, од којих су најважнији „Zaharija Orfelin als Philolog” и „О аутору и узору Славено-сербског магазина од 1768. год.”, које он у својој студији даље кратко спомиње. На њих ће детаљније бити упућено у списку литературе на крају рада.

Димитрије Руварац је, поред Тихомира Остојића, један од најзначајнијих проучавалаца грађе о Орфелину. Он спада у пионире модерне србистике заинтересованих за Орфелина, а његов допринос може се најбоље увидети из три чланка: „Ко је писац књиге: ‘Житіе и славныя дъла государя императора Петра Великаго ...', у коме доказује Орфелиново ауторство ове историјске монографије, потом „О првом штампаном словенском буквару за српску децу", где указује на постојање претходних верзија Орфелиновог до тада познатог буквара, као и чланка „Захарија Орфелин: животописно-књижевна црта". Последњи је од посебно велике важности, а у њему се, поред многих исечака из просветитељевог живота и дела његовог претходног помињања у литератури, Орфелин по први пут наводи као састављач Калиграpuje. Скреће се пажња и на постојање његових до тада непознатих дела, у рукописима - катихизиса „Апостолское млеко”, намењеног сину Петру, или превода „Правоверија, свјатија греческија церкве” (Руварац 1891: 83).

Од великог значаја су и чланци Николе Радојчића (1933) и Мите Костића (1921) о Захарији Орфелину. Први у чланку под називом „Захарија Орфелин као историчар", говори о Орфелну у светлу историјске вредности његових дела, а такође и изражава сумњу око ауторства две Орфелинове песме, наводећи своје аргументе. Сходно наслову чланка, највећи његов део посвећен је Житију Петра Великог, анализи коришћене литературе потребне за његово стварање, као и доношењу оцене о Орфелиновој интенцији приликом пи-

\footnotetext{
${ }^{3}$ Најконкретнија критика Остојићеве студије, на коју смо у свом бављењу темом наишли, дошла је од стране Бориса Унбегауна, чије ће дело „Почеци књижевног језика код Срба” такође бити овде представљено. Он наводи да је Остојићева (постхумна) књига „прилично нејасна”, као и да њеног писца готово уопште не занима Орфелинов језик и шири контекст његовог постојања (Унбегаун 1995: 60).
} 
сања овог дела. С друге стране, Мита Костић је Орфелину посветио кратак чланак под називом „Непозната дела Захарије Орфелина”, у коме је јавности представио до тада непознати Велики српски травник - „кратак српсколатински регистар биљака, трава, корења и других ароматичних ствари” (Костић 1921: 86), као и Славенски словар.

Крај једне епохе истраживања и почетак следеће могла би означити књига Бориса Унбегауна Почеци књижевног језика код Срба из 1935. године. ${ }^{4}$ Наиме, Унбегаун је пионир у својим погледима на рускословенски и славеносрпски период, и по први пут их не посматра искључиво у контексту извршене језичке стандардизације, већ покушава да од датог тока независно сагледа тадашње битне тенденције и активне појединце. Његова наведена критика Остојићу, чини се, односи се управо на њихов, према Унбегауновом схватању, различит приступ у овом аспекту. У Почецима књижевног језика код Срба Орфелин такође налази своје место, иако само у појединачним примедбама. Унбегаун углавном покушава да исправи оно што замера Остојићу, због чега он постаје први који је обратио пажњу на Орфелинов језик са филолошког аспекта (нпр., на доследност у увођењу рускословенских елемената и сл.).

3. Након Унбегаунове студије па све до шездесетих година двадесетог века, са изузетком неколико ретких чланака, о Орфелину из угла лингвистике није се писало готово ништа - искључујући неколико краћих чланака, повремена појављивања у делима о историји књижевности и спорадично објављивање песама у антологијама.

Што се тиче краћих чланака, један чији је аутор Васа Стајић појављује се исте године кад и Унбегаунова студија, под насловом „Нови подаци о Захарији Орфелину”, у Гласнику историјског друштва у Новом Саду. Он представља краћи извештај о Стајићевим открићима из Архива новосадског магистрата (Стајић 1935: 127). У чланку аутор доноси до тада непознате податке - име Орфелиновог оца (Јован) и своју претпоставку о његовом месту боравка у периоду од 1749. до 1756. године.

У ауторе важних прилога о Орфелину током средине двадесетог века спада и Крешимир Георгијевић. Године 1950. он пише чланак „Два непозната дела Захарије Орфелина", у којем приноси своја сазнања о двама списима написана на немачком језику - један у сврху оправдавања одредби Регуламента царице Марије Терезије, а други „Предлог о уређењу конзисторија, школа, архиепископа и епископа и њихових резиденција”. Његово најзначајније дело у овом контексту су ипак Кьижевне студије и огледи из 1952. године, у којем је поглавље под називом „Животни пут Захарије Орфелина” посвећено нашем просветитељу. ${ }^{5}$

Шездесете године двадесетог века означавају почетак препорода истраживања српске књижевности осамнаестог века и њених писаца. Као весник

\footnotetext{
${ }^{4}$ Нама је била доступна верзија књиге преведена на српски језик из 1995. године.

5 Чланак благо измењеног садржаја, под истим називом, објављен је и у Летопису Матице српске из 1946. године. Он се суштински не разликује од наведеног поглавља Георгијевићеве студије, али ће у сваком случају бити наведен у списку коначне литературе.
} 
нових лингвистичких тенденција појављује се 1960. године чланак Александра Младеновића „Прилог проучавању Орфелиновог језика”. Иако фокусиран на филолошке аспекте Орфелиновог стваралаштва (у чланку се анализирају Искусни подрумар, Плач Сербији, Мелодија к пролећу и писмо Орфелина синовцу Јакову), он продубљује приступ заступљен у Унбегауновим Почецима књижевног језика код Срба. Младеновић ће се у наредним деценијама испоставити зачетником новог погледа на језичку историју предстандардног периода.

Закључно са шестом деценијом прошлог века, битно је споменути и прилог Бернарда Џонсона (1966), „Неки видови песништва Захарија Орфелина". Он представља најозбиљнију анализу Орфелиновог песничког стваралаштва, како садржајно тако и риме, метрике и сл. Подаци о Орфелиновом стваралаштву појављују се у још једном делу већег обима - Српској библиографији 18. века Георгија Михаиловића из 1964. године. У њој се могу идентификовати Орфелинова до тада позната дела, са прецизним описима њиховог устројења по страницама, важнијим карактеристикама и ауторовим коментарима. ${ }^{6}$

4. У представљању доприноса насталим у седамдесетим годинама двадесетог века важнији доприноси Александра Младеновића би у том контексту били „Однос између домаћих и рускословенских елемената у књижевном језику код Срба пре његове вуковске стандардизације” из 1969. и „О неким рускословенским и српскохрватским језичким особинама у Орфелиновом Магазину" из 1970. године. Први је нешто општијег карактера, а тиче се језичке анализе Орфелиновог Искусног подрумара - овог пута у поређењу са језиком Павла Јулинца и Емануила Јанковића. ${ }^{7}$ У другом је заступљен сличан тип филолошке анализе, само овога пута урађене на примеру Славеносрпског магазина Захарије Орфелина. ${ }^{8}$ Младеновићеви чланци сакупљени су највећим делом у његовим књигама Славеносрпски језик и Историја српског језика: одабрани радови.

Године 1970. настала су још два значајна доприноса проучавању Орфелиновог рада - један у виду појединачног чланка, а други као књига нешто шире тематике. Први носи назив „Графијско-правописне одлике у Орфелиновом Магазину", аутора Светозара Стијовића, у којем је анализиран начин коришћења појединих графема или графијских секвенци у наведеном делу. Исте године је Милорад Павић објавио своју Историју српске кюижевности барокног доба (XVII и XVIII век), у којој Орфелин, због своје стваралачке

${ }^{6} \mathrm{O}$ Михаиловићевом доприносу истраживањима Орфелиновог опуса може се детаљније прочитати у чланку „Георгије Михаиловић о Захарији Орфелину” Боривоја Чалића (2004).

${ }^{7}$ Овај чланак је урађен на основу четрдесет страница узорка по једног дела наведених писаца. Орфелин се у свом писаном изражају, према Младеновићевим закључцима, налази „у средини", између претежно рускословенског Јулинчевог и претежно народног Јанковићевог језика. (Младеновић, 1969)

${ }^{8}$ Још детаљнијој морфолошкој, лексичкој и синтаксичкој анализи Орфелиновог Славеносрпског магазина посвећен је и докторат Ане Кречмер, под називом „Zur Methodik der Untersuchung älterer slavischer schriftsprachlicher Texte (am Beispiel des slavenoserbischen Schrifttums)" из 1989. године. 
свестраности, налази места у неколиким потпоглављима. Захарији Орфелину овде није посвећено засебно поглавље, али су његова дела спомињана у ширем контексту књижевних подврста - на пример у одељку о српском барокном песништву, или о историјским делима у контексту „барокног славизма" и сл.

5. Кроз седамдесете и даље осамдесете године прошлог века протеже се и рад Мирјане Бошков на славеносрпском питању и проучавању текстовне заоставштине српских писаца просветитеља. За разлику од Александра Младеновића, она је своје прилоге базирала на идентификацији културолошких поставки и историјских околности које су утицале на Орфелиново стваралаштво и коначно га дефинисали. Њени најважнији чланци су: „Руска штампана књига у нашем XVIII веку” (1973), „Захарија Орфелин и књижевност руског просветитељства” (1974), „Захарија Орфелин и млетачко издање Десјатословија Теофана Прокоповича” (1977), „Тип Орфелинова Магазина и руска периодика” (1979) и „Орфелинова Историја Петра Великог и одјеци идеје о Москви као трећем Риму” (1986).

Један од битнијих доприноса проучавањима стваралаштва Захарије Орфелина припада и Динку Давидову, у чијој књизи Српска графика 18. века из 1983. године наш просветитељ, заједно са Христифором Жефаровићем, бива посматран у контексту своје бакрорезне делатности.

У оквирима наведеног периода истраживања, важно је споменути и Боривоја Маринковића, који је науку задужио библиографским прилозима под називом „Bibliographia Orpheliniana”, 9 до данас најисцрпнијим списком литературе о Захарији Орфелину, као и „Изворима за Орфелинову преписку” из 1976. године.

Улазећи у модерније доба задржаћемо се на раду Лазара Чурчића, једног од најплоднијих писаца и сакупљача грађе о Орфелину. Чурчићеви чланци углавном су груписани у две књиге, под називом Српске књиге и српски писции 18. века (1988) и Кюига о Захарији Орфелину (2002). Прва књига покрива нешто ширу област изучавања, те чланци у њој заступљени нису обавезно посвећени Орфелину. Важнији за ову тематику ту су чланци „Повез српских књига штампаних у Венецији у штампарији Димитрија Теодосија од 1761. године” и „Српске повремене публикације 18. века”. Књига о Захарији Opфелину представља скуп чланака који покривају различите деонице његовог живота, елементе стваралаштва и сл. Од значаја нам је у овом контексту и Боривој Чалић, чији фокус интересовања лежи у проучавању прошлости вуковарских Срба. Поред великог броја написаних краћих чланака и прилога о Орфелину, Чалић се истакао као писац предговора Чурчићевој „Књизи о Захарији Орфелину” и приређивач књиге сакупљених Орфелинових дела из 2011. год. у издању Матице српске.

Два веома важна савремена аутора радова о Орфелину јесу и Владимир Симић и Јелена Тодоровић. Владимир Симић посветио је Орфелину, поред неколико чланака, и своју докторску дисертацију из 2013. године. Интересо-

\footnotetext{
${ }^{9}$ Први део библиографије је издат 1973, а други 1975. године.
} 
вање овог аутора, историчара уметности, за стваралаштво Захарије Орфелина има своје тежиште углавном на његовој бакрорезачкој делатности и оцени значаја за српску културну историју. На самом крају скренули бисмо пажњу на најновију студију Јелене Тодоровић из 2014. године, посвећену Орфелиновој првој сачуваној песми „Свечани поздрав Мојсеју Путнику”. ${ }^{10}$

На самом крају је битно, као значајне доприносе, издвојити и синтетичке прегледе настале у току претходних неколико деценија, а у којима се разматра и Орфелиново дело. Ту спадају Историја српске књижевности Ј. Деретића (1983) и Преглед историје српског језика П. Ивића (1988), као и Кратка историја српског језика А. Милановића (2010).

6. Као одређену врсту закључка представићемо систематизовану грађу рада у кратким цртама. Озбиљнија бављења Захаријом Орфелином у модерној србистици почињу занимањем Димитрија Руварца и Тихомира Остојића за његов живот и стваралачки опус, са краја деветнаестог и почетка двадесетог века. После неколико краћих чланака, средином тридесетих година прошлог века, светлост дана угледала је и Унбегаунова студија, са којом почињу изучавања Орфелиновог језика у контексту рускословенског и славеносрпског периода. Најважнији допринос у педесетим годинама двадесетог века дао је Крешимир Георгијевић својим Кюижевним студијама и огледимa, као и једним каснијим подужим чланком. На сцени научне србистике већ почетком шездесетих година са првим чланцима, па даљим доприносима који су се наставили у будућим деценијама, појављује се Александар Младеновић и оживљава филолошка изучавања језика славеносрпских писаца. Нешто касније се тој струји прикључује и Мирјана Бошков, са својим претежно историјско-културолошким разматрањима Орфелиновог дела. Значајним прилозима истакли су се и Лазар Чурчић и Боривој Чалић, као и у најскорије доба Владимир Симић и Јелена Тодоровић.

Чињеница је и да у садашњем времену српски просветитељ Захарија Орфелин заслужује више научне пажње од оне која му се поклања. Било проналажењем и анализом нове архивске грађе, филолошком анализом у контексту славеносрпског језичког наслеђа или историјско-културолошким посматрањима његовог стваралачког корпуса, важно је у будућности не препустити нашег пионира на различитим пољима, у много чему испред свог времена, научном забораву. Надам се да ће овај преглед послужити и барем донекле олакшати задатак наредним истраживачима српског осамнаестог века.

${ }^{10}$ У студију је, између осталог, укључена и транскрипција овог Орфелиновог дела. Објашњење поступка и његовог научног значаја дала је И. Бјелаковић (2016). 


\section{ЛИТЕРАТУРА}

Бјелаковић 2016: И. Бјелаковић, О транскрипцији Поздрава Мојсеју Путнику 3. Орфелина, Доситејев врт, IV, Београд, 125-133.

Бошков 1973: М. Бошков, Руска штампана књига у нашем XVIII веку, Годишњак Филозофског факултета у Новом Саду, XVI/2, 527-567.

Бошков 1974: М. Бошков, Захарија Орфелин и књижевност руског просветитељства, Зборник Матище српске за славистику, VII, 9-79.

Бошков 1977: М. Бошков, Захарија Орфелин и млетачко издање Десјатословија Теофана Прокоповича, Зборник Матице српске за књижевност и језик, XXV, 41-85.

Бошков 1979: М. Бошков, Тип Орфелинова Магазина и руска периодика, Зборник радова Института за стране језике и књижевности, I, Нови Сад, 223-239.

Бошков 1986: М. Бошков, Орфелинова Историја Петра Великог и одјеци идеје о Москви као трећем Риму, Зборник Матице српске за књижевност и језик, XXXIV/2, 173-225.

Давидов 1978: Д. Давидов, Српска графика XVIII века, Београд: Нолит.

Георгијевић 1946: К. Георгијевић, Животни пут Захарије Орфелина, Летопис Матище српске, CCCLVII/1, 42-54.

Георгијевић 1950: К. Георгијевић, Два непозната дела Захарије Орфелина, Историјски гласник: Орган Историјског друштва СРС, III, Београд, 63-96.

Георгијевић 1952: К. Георгијевић, Кюижевне студије и огледи, Нови Сад: Матица српска.

Костић 1928: М. Костић, Непозната дела Захарије Орфелина, Гласник Историског друштва у Новом Саду, I, Нови Сад, 86-92.

Кречмер 1989: A. Kretschmer, Zur Methodik der Untersuchung älterer slavischer schriftsprachlicher Texte (am Beispiel des slavenoserbischen Schrifttums), München: Sagner Verlag.

Кречмер 1996: А. Кречмер, О феномену тзв. Pax Slavia Orthodoxa у контексту историје словенских стандардних језика, Научни састанак слависта у Вукове дане, 25/2, 31-41.

Кречмер 2000: А. Кречмер, О књижевно-језичкој традицији до 1800. код Срба и Руса (размишљања о словенској историјској стандардизацији), Јужнословенски филолог, LVI/1-2, 543-559.

Маринковић 1973: Б. Маринковић, Bibliographia Orpheliniana, Годишњьк Филозофског факултета у Новом Саду, XVI/2, 859-896.

Маринковић 1975: Б. Мариковић, Bibliographia Orpheliniana, II, Годишъак Филозофског факултета у Новом Саду, XVIII/2, 805-835.

Маринковић 1976: Б. Маринковић, Извори за Орфелинову преписку, Библиотекар, XXVIII/3-4, Београд, 495-514.

Михаиловић 1964: Г. Михаиловић, Српска библиографија XVIII века, Београд: Народна библиотека СР Србије.

Младеновић 1960: А. Младеновић, Прилог проучавању Орфелиновог језика, Зборник Матице српске за филологију и лингвистику, III, 153-174. 
Младеновић 1969: А. Младеновић, Однос између домаћих и рускословенских елемената у књижевном језику код Срба пре његове вуковске стандардизације, Зборник Матице српске за филологију и лингвистику, XII, $43-51$.

Младеновић 1970: А. Младеновић, О неким рускословенским и српскохрватским језичким особинама у Орфелиновом Магазину, Зборник Матище српске за филологију и лингвистику, XIII, 103-118.

Младеновић 1989: А. Младеновић, Славеносрпски језик: студије и чланци, Нови Сад: Књижевна заједница Новог Сада - Горњи Милановац: Дечје новине.

Младеновић 2008: А. Младеновић, Историја српског језика: одабрани радови, Београд: Чигоја штампа.

Остојић 1908: T. Ostojić, O autoru i uzoru Slaveno-serbskog Magazina od 1768, Zbornik u slavu Vatroslava Jagića, Berlin, 681-690.

Остојић 1909: T. Ostojić, Zaharija Orfelin als Philolog, Archiv für slavische Philologie, XXX, Berlin, 448-452.

Остојић 1923: Т. Остојић, Захарија Орфелин, живот и рад му, Београд: Српска краљевска академија наука.

Павић 1970: М. Павић, Историја српске књижевности барокног доба (XVII и XVIII век), Београд: Нолит.

Радојчић 1933: Н. Радојчић, Захарија Орфелин као историчар, Гласник Историског друштва у Новом Саду, VI, 253-280.

Руварац 1887: Д. Руварац, Ко је писац књиге Житіе и славныя дњла государя императора Петра Великаго Въ Венеціи 1772?, Јавор, Х, Нови Сад, $151-167$.

Руварац 1891: Д. Руварац, Захарија Орфелин: животописно-књижевна црта, Споменик СКА, Х, Београд, 75-91.

Руварац 1893: Д. Руварац, О првом штампаном словенском буквару за српску децу, Годишњища Николе Чупића, VIII, Београд, 263-290.

Симић 2013: В. Симић. Захарија Орфелин (1726-1785), [докторска дисертација], Београд: Филозофски факултет.

Симић 2016: В. Симић, Име и знак: о псеудониму Захарије Орфелина, Прилози за књижевност, језик, историју и фолклор, LXXXII, 75-87.

Стајић 1935: В. Стајић, Нови подаци о Захарији Орфелину, Гласник Историског друштва у Новом Саду, VIII, 127-130.

Стијовић 1970: С. Стијовић, Графијске и правописне одлике у Орфелиновом Магазину, Прилози проучавању језика, VI, 31-40.

Тодоровић 2014: Ј. Тодоровић, Свечани поздрав Мојсеју Путнику Захарије Орфелина, Нови Сад: Платонеум.

Толстој 2004: Н. И. Толстој, Студије и чланции из историје српског књижевног језика, Београд: Завод за уџбенике, Вукова задужбина - Нови Сад: Матица српска.

Унбегаун 1995: Б. Унбегаун, Почеии књижевног језика код Срба, Београд: Вукова задужбина, Орфелин - Нови Сад: Матица српска. 
Хорањи 1776: E. Horányi, Memoria Hungarorum et Provincialium scriptis editis notorum, Band II, Wien: Impensis Antonii Loewii, bibliopolae posoniensis.

Чалић 2004: Б. Чалић, Георгије Михаиловић о Захарији Орфелину, Сусрети библиографа у спомен на др Георгија Михаиловића, XIV, Инђија, 107-123.

Чалић 2011: Б. Чалић, Захарија Орфелин, Нови Сад: Издавачки центар Матице српске.

Чурчић 1988: Л. Чурчић, Српске књиге и српски писии 18. века, Нови Сад: Књижевна заједница Новог Сада.

Чурчић 2002: Л. Чурчић, Кьига о Захарији Орфелину, Загреб: СКД Просвјета.

Џонсон 1966: Б. Џонсон, Неки видови песништва Захарије Орфелина, $y:$ М. Павић [ред.], Од барока до класицизма, књ. III, Српска књижевност у књижевној критици, Београд: Нолит, 127-184.

Aleksandra Gagic

\section{REPRESENTATION AND RECEPTION OF ZAHARIJA ORFELIN IN MODERN SERBIAN LINGUISTICS RESEARCH}

\section{Summary}

The language period preceding the standardization of the Serbian literary language on basis of a national vernacular by Vuk Stefanović Karadžić, better known as the Slavonic-Serbian period, although important for Serbian historical linguistics, was largely neglected after the language reform. Along with it, many important people, to whom Serbian science and culture remained largely indebted, almost fell into oblivion. According to the author, Zaharija Orfelin can be found among them - which is why the examination of the reception of his character and work in the context of Serbian modern (poststandardization) linguistics were defined as the topic of this paper. Accordingly, the paper provides a bibliographic review of selected available literature on Zaharija Orfelin, which is hoped to prove its usefulness for future science and further scientific research.

Keywords: Zaharija Orfelin, Enlightenment, historical Serbian studies, bibliographic review. 